\title{
Optimizing the cost of accounting work and financial rules within the framework of outsourcing
}

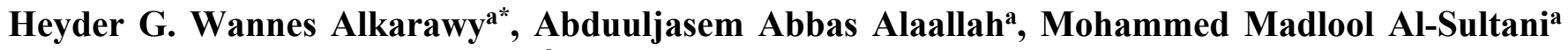 \\ and Olga Leonidovna Ostrovskaia ${ }^{b}$
}

${ }^{a}$ Department of Accounting, Faculty of Administration \& Economics, University of Babylon, Republic of Iraq

${ }^{b}$ Department of Accounting and Analysis, college of Economics and Finance, St. Petersburg State Economic University, Russia

\section{H R O N I C L E}

\section{Article history:}

Received: January 1, 2021

Received in revised format:

April 32021

Accepted: April 4, 2021

Available online:

April 6, 2021

Keywords:

According

Outsourcing

Outsourcing center

Operating costs

Transaction costs

\section{A B S T R A C T}

\begin{abstract}
This study aims to propose and apply a systematic and descriptive presentation of the costs of administrative coordination and organizational costs for a third-party company in the manufacturing enterprises of individual business functions. As for the procedures, it is a bibliographic research, based on Design Science Research, which proposes a new artifact based on the review of the literature and which starts to be applied based on the Iraqi Financial Control Council and Financial rules followed to achieve financial discipline. Special methods in which it was chosen to apply techniques such as observation, it is a practical means of cognition determining costs revenue that help to understand and identify the problems of the implementation of the main functions of financial, accounting and administrative performance. The research proposes the classify costs according to the types of industrial objects, contracts, and agreements based on the requirements of standard No. 1 "Measurement of performance results under employment contracts.
\end{abstract}

(C) 2021 by the authors; licensee Growing Science, Canada

\section{Introduction}

Flexibility to deal with cyclical fluctuations is of great importance, especially in good times, whether at the governmental or institutional level, which leaves enough room for a response against economic cycles and bad and unfavorable conditions .A viable approach has been guided to achieve its objectives, through the financial rules, which are permanent numerical restrictions placed on groups defined by numerical targets by defining the operational indicator that they apply to in order to direct the financial policy and are characterized by simplicity and ease of monitoring, operation and transmission of beneficiaries, and serving multiple goals Foremost among them is enhancing financial sustainability, as governments or institutions resort to adopting financial rules in order to achieve a number of goals, the most important of which are the following:

Absorbing costs and setting up a coordination framework for the best mix of monetary-fiscal policy to mitigate these impacts, which include fiscal rules and frameworks in the medium term. Through the revenue base that specifies the upper and lower limitations of the expected revenues that are important in the financial policy strategy of the institutions in general because of their impact on the issues of choosing accounting methods. The issues of choosing accounting methods that correspond to the potential of manufacturing enterprises are so important on the grounds that the manufacturing enterprises, when defining a strategy, devoting all its resources and efforts to implement accounting methods. The strategy should include a comparison of

* Corresponding author.

E-mail address: bus.heyder.wannes@uobabylon.edu.iq (H. G. W. Alkarawy) 
cost and operating costs throughout the product life cycle (Syutkina, 2012). Outsourcing can be considered as an additional source of resources for the manufacturing enterprises capabilities (Алькарави, 2018; Abdulwahab et al., 2019). When Manufacturing enterprises use outsourcing, primarily in the area of high private costs. The determining factor in favor of outsourcing is cost saving (Abdulwahab, Alwan, Jasim, \& Jasim, 2019). One of the main goals of outsourcing is to save costs in satisfactory sizes (De et al., 2020). Management accounting is effective when it reflects the activities of enterprises through a balanced system of responsibility centers. Cost Accounting System the information used for financial accounting purposes and for administrative accounting purposes to take the various applied and specific decisions within the unified system accounting in Iraq faces many problems, in addition to not addressing aspects of outsourcing operations so this system must be improved Nassif, and Hassanein (2016). Comparison of international and local practices of accounting transformation in the context of outsourcing made it possible to cause a lag in the volume and quality of these services in the Iraqi accounting practice. There is no clear mechanism for monitoring the use of outsourcing that is uniform in appearance in its economic nature and how accounting is organized for this purpose (Kim et al., 2016). Cost accounting within the framework of the unified accounting system at this stage is not feasible to perform its functions in the areas of cost measurement for outsourcing and rational decisionmaking in production units (Hanan, 2015). This paper turning provides to fill this shortcoming within the framework of the unified accounting system in the outsourcing of Iraqi companies.

\section{Literature review}

The activity of industrial enterprises in Iraq indicates that costs are considered as an object of accounting, while market conditions require mandatory analysis and as an object of management. Cost management is an important element of farm management, which should facilitate the adoption of sound management decisions to stop the production of unprofitable products, setting prices for individual products, building a system of internal (management) accounting. It is necessary to determine the operating costs that are transaction costs, but also transaction costs, namely, management coordination costs and organizational costs for pre-contractual work and the conclusion of the contract itself of particular importance, while seeking to reduce them (Rehab, Abdulwahab, \& Amel, 2019). Given the multiplicity of processes through which the product reaches full readiness and designed for implementation at the production stage, the accounting system should provide for a special account of outsourcing costs for all products (Matyushina, 2015). Current conditions and projected future economic conditions, available at the reporting date without undue cost and effort (Luc, \& Luis, 2019). Therefore, in order to provide the accounting information that meets the needs of the departments of the institutions in the accounting framework, it requires updating and improving accounting, and focusing mainly is on the cost accounting aspect in it, so that it meets the efficiency of financial, accounting and administrative performance in industrial institutions. On the one hand outsourcing objects are not uniform in appearance, by their economic nature, this raises the problem: how to organize their accounting - only according to the rules of financial accounting, or as part of management accounting, or with their integrated system. For the purposes of this study, an integrated system is proposed that includes the following elements:

- classification and identification of costs;

- additional analytical positions;

- financial accounts and sub-accounts of the second and third order opened to them;

- methods for organizing outsourcing costs;

- ways of disclosing outsourcing costs in financial statements.

The classification (from latin. classis discharge and facere do) of production costs in the Dictionaries and Encyclopedias on the Academician is indicated: "Classification - the division of many objects into subsets according to their similarity or difference in accordance with accepted classification methods" (Matyushina, 2013). The paper provides a systematic and descriptive presentation of the costs of administrative coordination and organizational costs of work in institutions. In this case, it requires the use of new tools to deal with financial affairs related to the transfer of activities to outsourcing. It was submitted to a proposal to introduce an additional responsibility center "the center of outsourcing" in the accounting system, which will work on the effectiveness of the decisions taken to use the benefits of outsourcing in industrial enterprises. Also offer an approach to pooling accounts for outsourcing contracts according to the expanded type of work from the classification of cost accounting items for the accounting system in Iraq. The application of the developed approach allows improving the costing methodology and provides project management with the analytical information needed to make decisions when using the outsourcing contract.

\section{Methodology}

Given its characteristics, the research corresponds to on theoretical applied approach, descriptive type and special methods in which it was chosen to apply techniques such as observation, it is a practical means of cognition determining costs, as well as the process of occurring costs or revenue that help to take into differences in the nature of managerial responsibility make it possible to identify the main types of responsibility centers in the accounting system. Primary sources such as direct observation, which had the purpose of exploring the role of accounting functions are considered, fields of activity, were used to understand 
and identify the problems of the implementation of the main functions of accounting (Roller, 2013). This method allowed for detailed events, conditions or situations, being able to use figures, qualities of responsibility centers with the characteristics of the organization. In addition, according to the basis of the standard for employment contracts, the classify costs according to the types of industrial objects, contracts, and agreements based on the requirements of standard No. 1 "Measurement of performance results under employment contracts. On the other hand, a variety of secondary sources were used to supplement the initial level of accounts with second and third levels of accounts, with the development of this article, if the intention is chart of accounts can use in terms of solving the problem of outsourcing, which leads to will improve the quality of accounting information and its use will facilitate the adoption of the right management decisions in this area.

\section{Results}

Cost centers help provide accounting information (costs, expenses incurred, income, situation /center financial), and to improve the efficiency of production management of products (works, services), the scientific organization of production, labor and its payment in commercial organizations is of great importance. For this purpose, in practice, organizations can apply different forms of centers of financial responsibility by decentralizing part of the management system and delegating certain powers to subdivisions of a given economic entity. So, in accordance with the delegation to the units of the degree of organizational and economic and financial independence, which determine the choice of one or another mechanism of internal economic relations, and for the prepare decisions on the transfer of accounting for outsourcing costs, and for the purpose of the use of outsourcing in companies, according to the role of the cost center is to distribute the responsibility centers in the accounting system for the purpose of effectiveness of the decisions taken to use these centers, as in Table 1.

Table 1

Types of responsibility centers

\begin{tabular}{cl}
\hline № & Name of responsibility centers \\
\hline $\mathbf{1}$ & Cost center \\
$\mathbf{2}$ & Revenue center \\
$\mathbf{3}$ & Profit center \\
4 & Outsourcing Center \\
\hline Source: The author's elaboration &
\end{tabular}

From Table 1, notes the differences in the nature of managerial responsibility make it possible for subdivisions receive partial independence, work under the conditions of observing the level of planned costs, and it resulted in four centers of financial responsibility:

- the cost center is where their managers are responsible for the costs that arise in them;

- the center of income is the union of responsibility for the expenses incurred and income received by the structural unit of the enterprise or a technologically related group of production units;

- the profit center can be represented in this status if the structural unit of the enterprise or a technologically related group of production units reflects in the internal reporting the difference between income and expenses;

- outsourcing Center - a structural unit or a group of organizational units, the leaders of which are responsible for the effectiveness of decisions made to use the benefits of outsourcing.

In any form of organization of responsibility centers, it is important that the subdivisions bear responsibility for the final results, interact with the organization and other subdivisions on the basis of the development of internal settlements for products, services, material resources. The above conditions and the model of economic relations meet the requirements for the creation of centers of financial responsibility based on the decentralization of management in the organization. Decentralization of the management system and the organization of financial responsibility centers should precede the rationalization of intra-industrial relations in organizations for the effective management of the production activities of departments by constantly assessing the results of their production and financial activities on the basis of relevant accounting and control information. This form of responsibility centers can be viewed as a transitional form with a broader independence of units. Therefore, the strategic direction of management accounting for the activities of financial responsibility centers should be focused on providing information to the cost management system and the results of the activities of production units of enterprises. The main functions of this management system at the level of responsibility centers should be: forecasting; business planning of production and results of activity of centers of responsibility; rationing, control, analysis of costs and production cycle; accounting and calculating the cost of production; regulation of business processes. Through this, such researchers as Hassan (2000), Alsalm (2001), Ali (2002) suggest using classification features of responsibility from the point view of the organization's cost management: "the center of responsibility is a segment of activity, within the framework of which the personal responsibility of the manager for the efficiency of the structural unit that he controls it". Also supports this case Roller (2013). Thus, this diagnosis allows us to study 
organizational and production features, taking into account as in Fig. 1: organizational and production features (cost centers ، revenue centers 'profit centers 'outsourcing centers); regarding the production process (basic and functional); by the degree of consolidation of expenses (based on outsourcing).

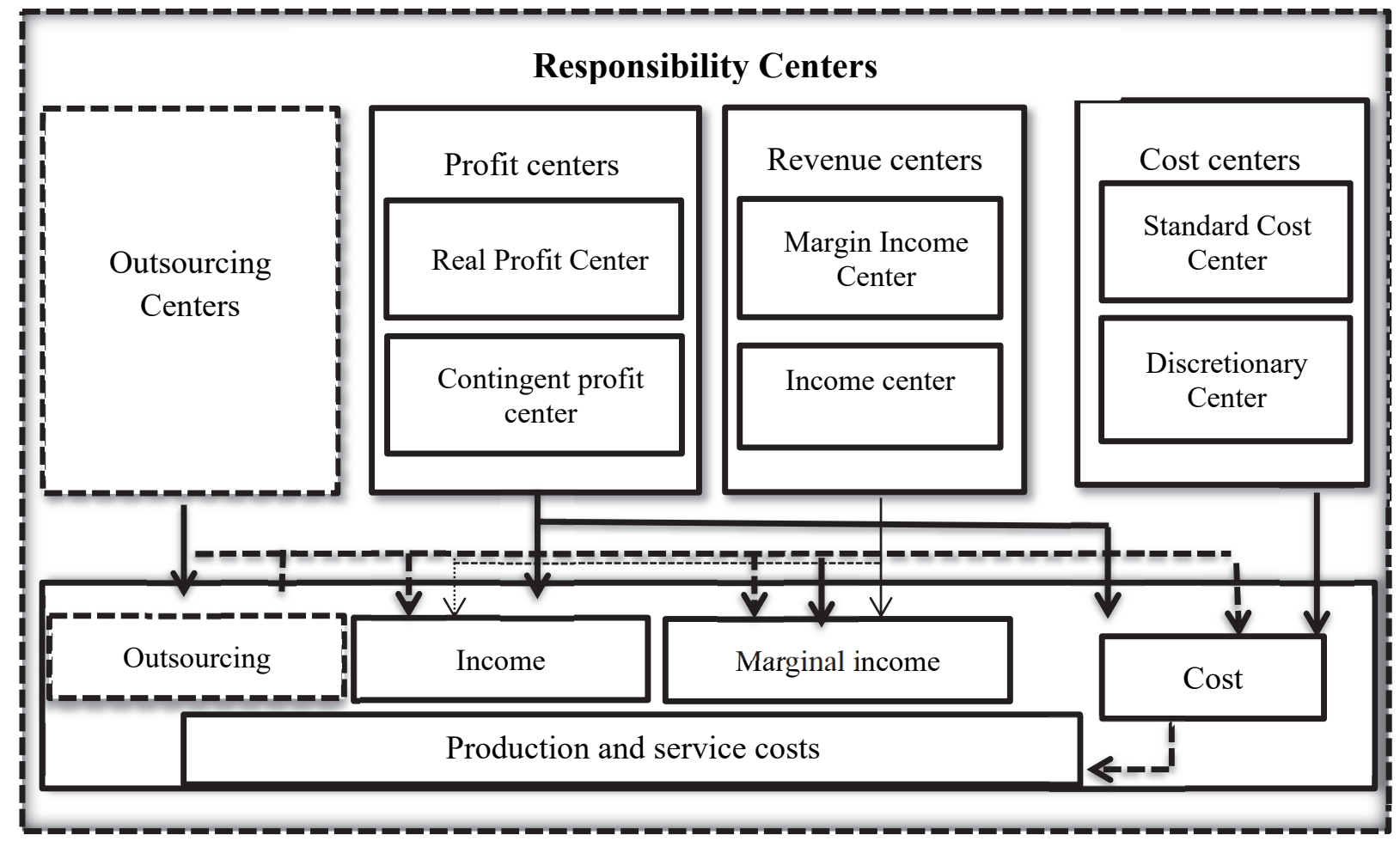

Source: The author's elaboration

-....... - suggested by the author

Fig. 1. Objects of various responsibilty centers

Fig. 1 includes the requirements for an outsourcer when transferring to him the maintenance of this accounting section should contain: compliance of responsibility centers with the characteristics of the organizational structure of the organization; regular preparation of internal reports on the volume of work and the cost of their implementation; identifying and analyzing the causes of deviations, evaluating the activities of responsibility centers according to the indicators established for each of them.

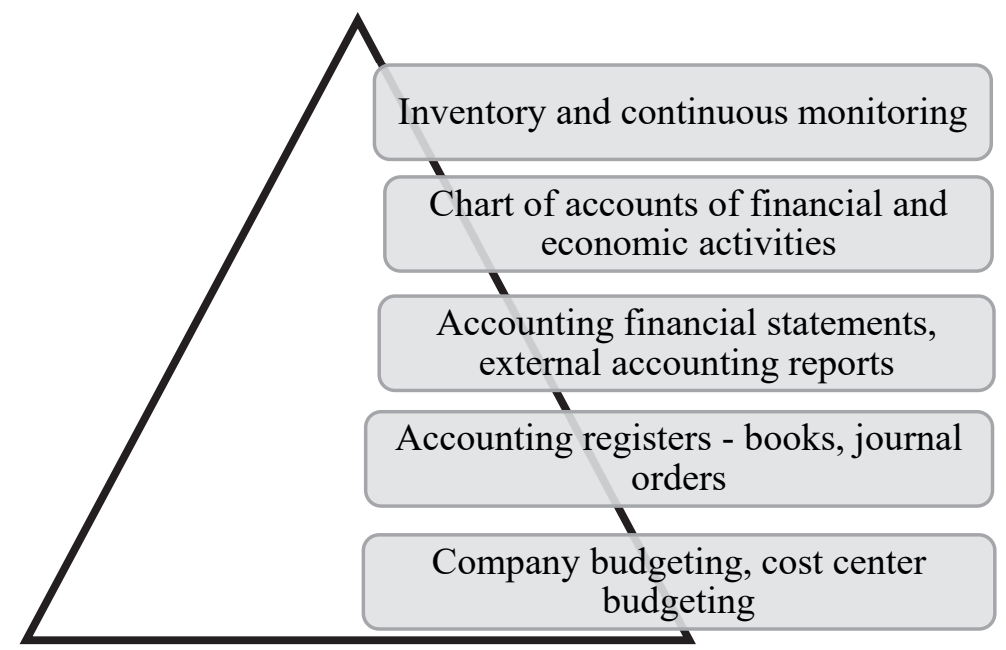

Fig. 2. Elements of the Unified Accounting System of Iraq 
There should also be an optimal information management system for business relations in Iraq applying a system of accounting regulation. In each individual country, regulation has its own characteristics, which lead to opportunities, using common features of systems, groupings or the creation of so-called "models of national accounting systems" (Anglo-American, Continental, Latin American and Islamic). The need for state regulation of economic processes is due to the emergence of negative external market factors at each moment of time. The analysis of the Iraqi unified accounting system content made it possible to single out the following elements of the system in Fig. 2. Budgeting as separate budgets includes such indicators as: the volume of commodity production, service and sales, labor resources, the introduction of additional capacities, etc. In general, budgeting is aimed at ensuring the relationship between the organization's budget and the budgets of cost centers. Therefore, it is necessary to create appropriate conditions for a fuller use of their internal production and economic potential. It also requires a thorough substantiation of the principles for establishing the size of the main on-farm units, organizing management accounting and control over their activities. Thus, information is reflected in the cost accounting system due to the methodological unity of synthetic accounting accounts and the disclosure of analytical processes. The application of the developed approach allowed to improve the accounting methodology for costs according to the responsibility centers of industrial enterprises, provides enterprise management with the necessary analytical information for making decisions when using contract outsourcing. In the framework of this task and in accordance with the provision on the recognition of financial statements and clarification of financial statements for usage in the accounting system, which in turn considers questions of methods of calculating the cost, which are used are attributed to the cost of production (Jasim, \& Mahdi, 2019). At the same time, the conclusion of long-term outsourcing contracts must be preceded by preliminary financial and economic calculations based on the results of the separation of certain functions, defined by law annual financial statements that serve as the basis for accounting information for interested users (Heyder, 2018). Using the principle of analyticity means that charts of accounts provide information with such details and generalization, which meets the needs of the relevant levels of management with the available information systems.

\section{Discussion}

After analyzing the cost elements, the practical and rational use of the study methods is the functional role of production costs for the reasons summarized below into:

- helps in maintaining the quality of industrial business by giving; reports and specific measurements for each company - it helps the administration to control the quality of the industrial business through it ;

- assists management in monitoring compliance with engineering processes by determining the size of the company through production costs and comparing them with costs of its external components (Uliana, 2013);

- it is through costs that the decentralized and decentralized system is linked to them in the organizational structure. Appends decentralized structure, which reports on amendments within the accounting process, that is, in the accounting system.

Cost apportionment is important to the accounting system such a division is based on the principle of dividing activities into areas. Moreover, the types of activities can be considered autonomous and separated in accounting if they have different cost behavior with changes in the volume of production, affect price differentiation and company value, but also taking into account the hidden savings, which is associated primarily with the reduction of the number of management and control objects (Skakun, 2015). The classification basis under consideration acts as a systematic information base for management. This classification is aimed at finding reserves to reduce costs in the event that accounting is organized in accordance with accepted standards and meets the criteria by different reasons:

- the principle of consistency, the application of which ensures compliance with the methodological unity of the formation of economic indicators on sub-accounts and analytical accounts throughout the vertical of the Chart of Accounts, the allocation of accounts for settlements with outsourcers;

- the principle of analyticity, the compliance with which allows you to refine information in accordance with the needs of management at different levels of management and the available capabilities of the information system.

At the conclusion of an activity outsourcing agreement, the organization, as well as contracts or a special agreement with organizations, the costs associated with it may be charged to operating expenses by types of activities of the organization in equal parts during the term of the agreement (Sabah, 2015). It is classified on the basis of the assessment and the method of measuring activity (completion rate or the total amount of the contract) in accordance with the result. The organization that provides outsourcing services can form both the full and production costs of services, choosing a basis for the distribution of indirect costs, take into account services at actual or planned costs. From this aspect, these costs are important for the purpose of evaluating the effectiveness of any economic unit. Fig. 3 shows the classification of costs according to the types of industrial objects, contracts, and agreements based on the requirements of standard No. 1 "Measurement of performance results under employment contracts. Accounting rule No. (1) The unified budget accounting systems Iraq (IFCC, 2011; MFA, 2015), 
statement on the standard measure of activity as a result of employment contracts. According to the basis of the standard for employment contracts, it is classification of costs as follows.

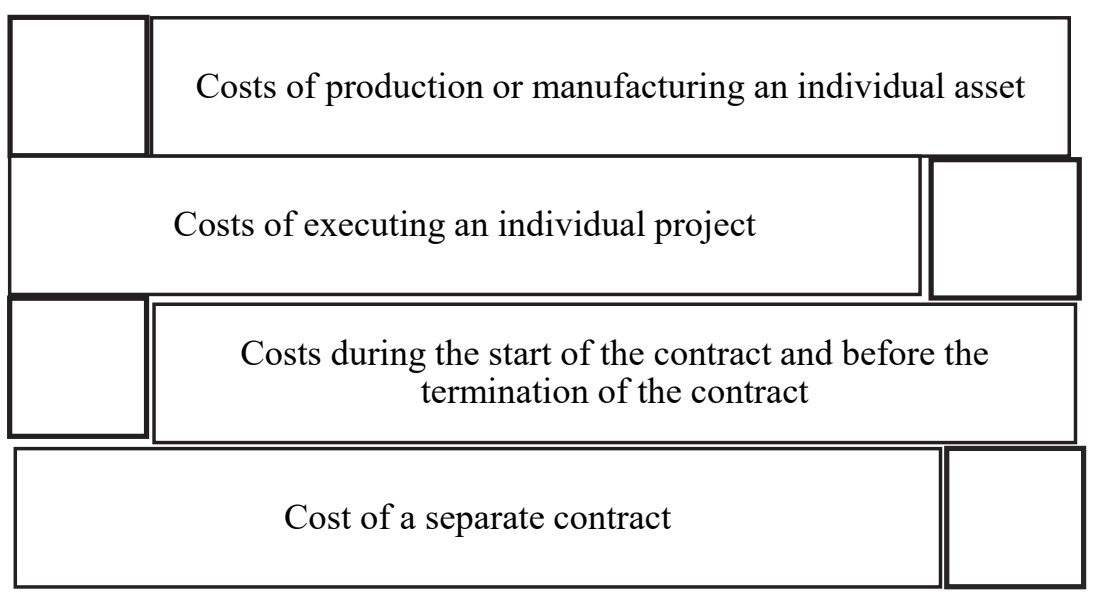

Source: The author's elaboration

Fig. 3. Classification of costs according to standard No. 1 of unified budget accounting systems Iraq

The application includes consideration of accounting for outsourcing contracts assessment of the financial performance of these contracts in reports and final reports, and the application of accounting rule No. (1) relating to this issue. Through this classification, the value of an object or group of objects included in one project, when it is transferred by a construction organization to a customer or investor, also serves as the basis for determining and recognizing the financial result for each contract, agreement \& object. Due to the costs of a separate contract allows to take into account and disclose the content of the following parameters: contract costs; the costs of the structural units of the enterprise; assessment of the effectiveness of outsourcing operations, which is one of the prerequisites for choosing the form of organization of accounting, which is the most suitable for use in the organization, to determine the appropriateness and effectiveness of outsourcing. As well as the information currently being generated on the accounts of the Chart of Accounts, and to determine the risk of outsourcing operations in industrial enterprises and to calculate the efficiency of transfer of assets, management functions, and control information of a third-party organization, must be completed supplement the initial level of accounts with second and third levels of accounts as in Table 2 depending on the scheme, Iraqi Financial Control Council (2011).

Table 2

Cost accounting accounts for responsibility centers (production accounting accounts)

\begin{tabular}{cccc}
\hline & & Unified budget accounting systems Iraq & \\
\hline № code & Account name & 31 & Subaccount Name \\
\hline 5 & Production accounts & 32 & Wages \\
& 33 & Administrative services \\
& 34 & Service Requirements \\
& 36 & Contracting and Services \\
& 37 & Benefits of Debt and Land Lease \\
\hline 6 & Production Service & 38 & Waste \\
& Accounts & 31 & Production Costs \\
\hline & 32 & Salaries \\
& 33 & Product Requirements \\
& & 37 & Service Requirements
\end{tabular}

Source: The author's elaboration

The accounting policy during the development of a working chart of accounts can record or continue to analyze information on analytical sub-accounts according to management requirements. So, the components included in the system presented here allow us to control actual expenses and future revenue in order to operate on preliminary and final economic results (income or loss), which contributes to the organization of the accounting system for responsibility centers. In the developed system of analytical accounts, a special place is occupied by the reformation of account 32 "Administrative expenses". In our accounting system, 
expenses associated with paying for the services of an outsourcing organization are reflected in the debit of account 32 (Administrative expenses) in correspondence with account (Services of third-party organizations). Subsequently, these expenses are written off to the account of financial results. The write-off of these expenses is reflected in accounting for the debit of account 41 (Financial results) in correspondence with the credit of account 32 (Administrative expenses), chart of accounts of the Republic of Iraq (MFA, 2015). The cost of outsourcing services is accrued at the time (date) of drawing up the relevant act (or other document) on the provision and acceptance of services, when there is an obligation to the contractor to pay for its services (Alkarawy, 2013). It is necessary, subject to the use of outsourcing services in the organization, to add synthetic accounts to analytical sub-accounts of cost accounting. In particular, to allocate a separate sub-account designed to account for outsourcing costs. In addition, it is advisable to further divide (the organization of analytical accounting) of analytical positions in the following areas:

- types of outsourcing objects (often an organization outsource not one, but several business processes);

- duration of the contract;

- types of outsourcer services.

The process of using the system provides flexibility to the functions of traditional accounting (observation, measurement, systematization and reflection on accounts), economic analysis and planning. Costs are grouped according to the accounting system, which is consistent with the enlarged types of work according to the Classifier of cost accounting items in the Unified Accounting System in Iraq. Fig. 4 shows the structure of sub-accounts and analytical accounts of administrative expenses.

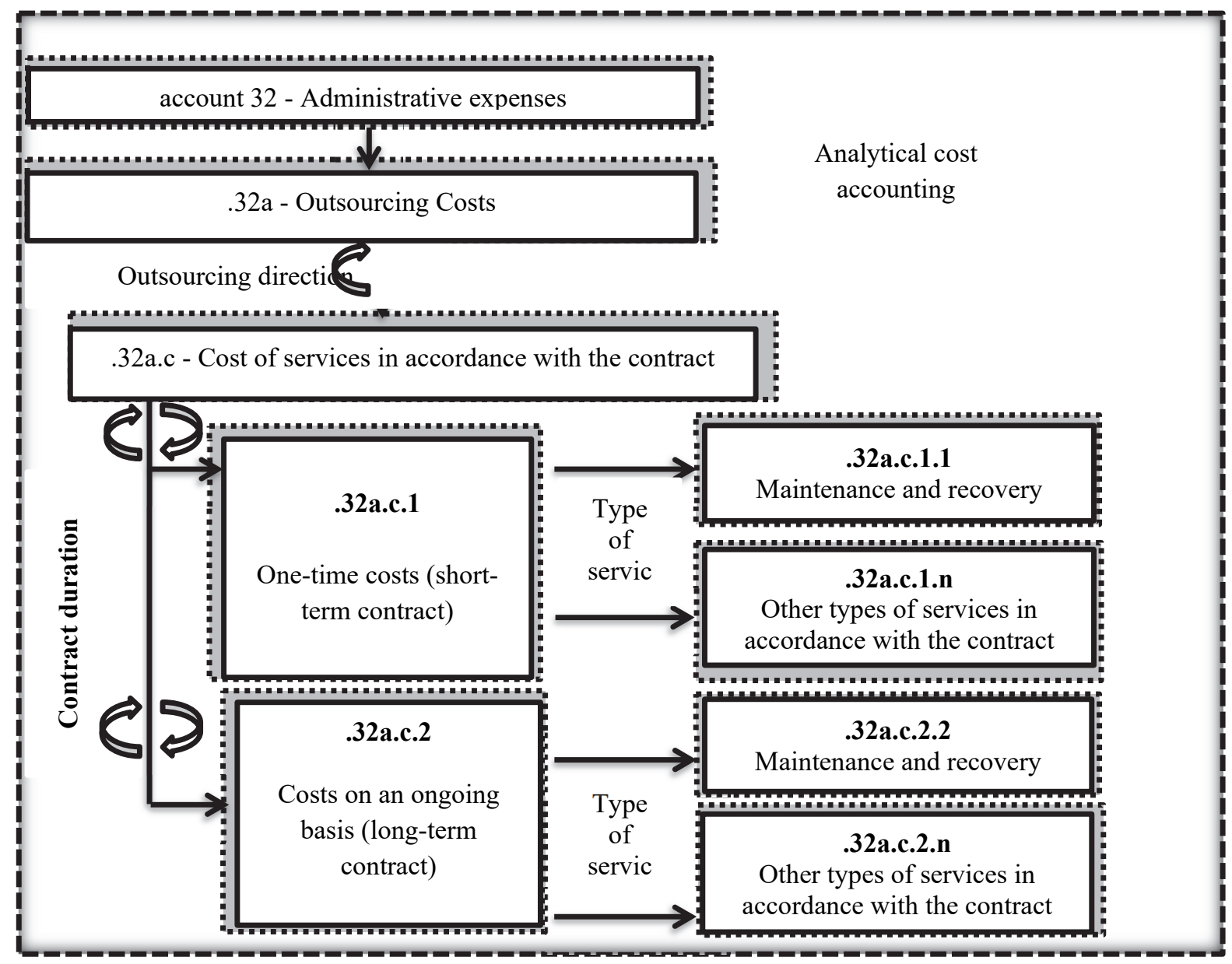

Source: The author's elaboration

Fig. 4. Proposed account structure (Administrative expenses) in terms of cost reflection for outsourcing agreements 
For the rational organization of production and management accounting of costs by financial responsibility centers, it is necessary to expand the list of cost accounting objects (Sabah, 2015; Bailal, 2018). For clarity and practical necessity, we schematically show the structure and content of the proposed variance of the organization of management accounting of costs by financial responsibility centers (production costs, service costs ) of outsourcing center operations, Fig. 4 illustrates the system to provide analytical sub-accounts for the account "production, service costs", which should be mandatory in the working chart of accounts, a separate block of accounting positions where information is generated on outsourcing centers, namely: open subaccounts to account "Contracting services (Outsourcing agreements). Such an organization of management accounting should contribute to the efficiently interrelated functioning of its content and form in Fig. 5.

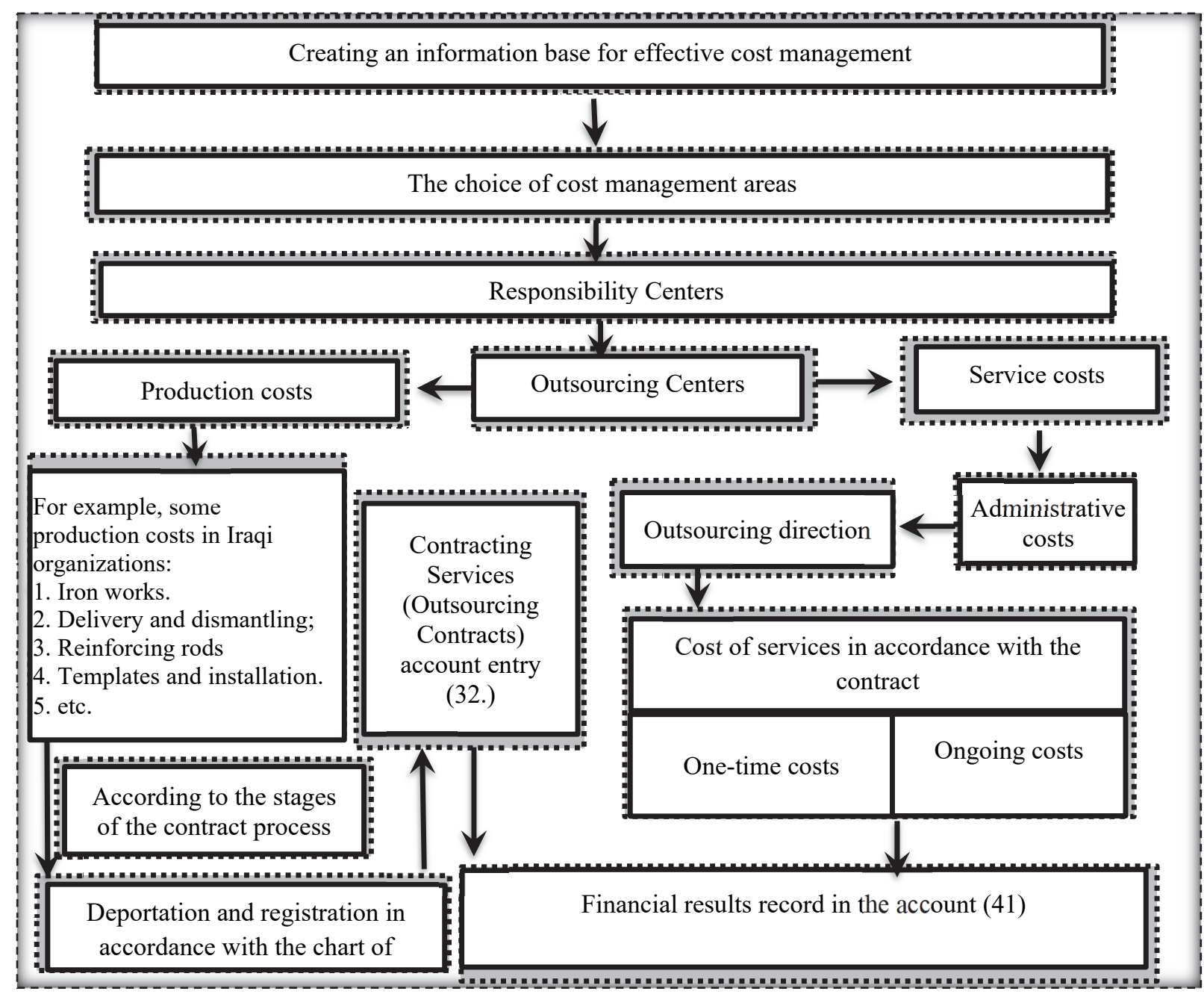

Source: The author's elaboration

Fig. 5. Directions for improving the Chart of Accounts

These costs can be analyzed in various aspects, including from the point of view of the "cost" of regulatory and supervisory support for entering into and implementing outsourcing agreements to Iraqi industrial firms. In contrast, the breakdown of these costs will make it possible to implement support operations effectively to make management decisions when transferring noncore business processes to outsourcing, as well as obtain reliable accounting data about all costs, which contributes to improving the quality of services, reducing prices, and saving Labor resources, as well as increasing industry transparency. Through the practical application of these accounts in the in the General Company for the implementation of projects, and this is one of the companies operating in the Iraqi market and based on the proposed coding of cost lines for outsourcing management and analytical sub-accounts of Account 32 "Contract Service", we propose a scheme for accounting support for costs of outsourcing in accounting accounts (Fig. 5). A transcript of the processes is shown in Table 3. Account element structure 32 "Contract Service" to record total outsourcing costs, including contract cost, cost of provision, etc. The following sequence will represent the analytical sub-accounts presented in Fig. 6. 


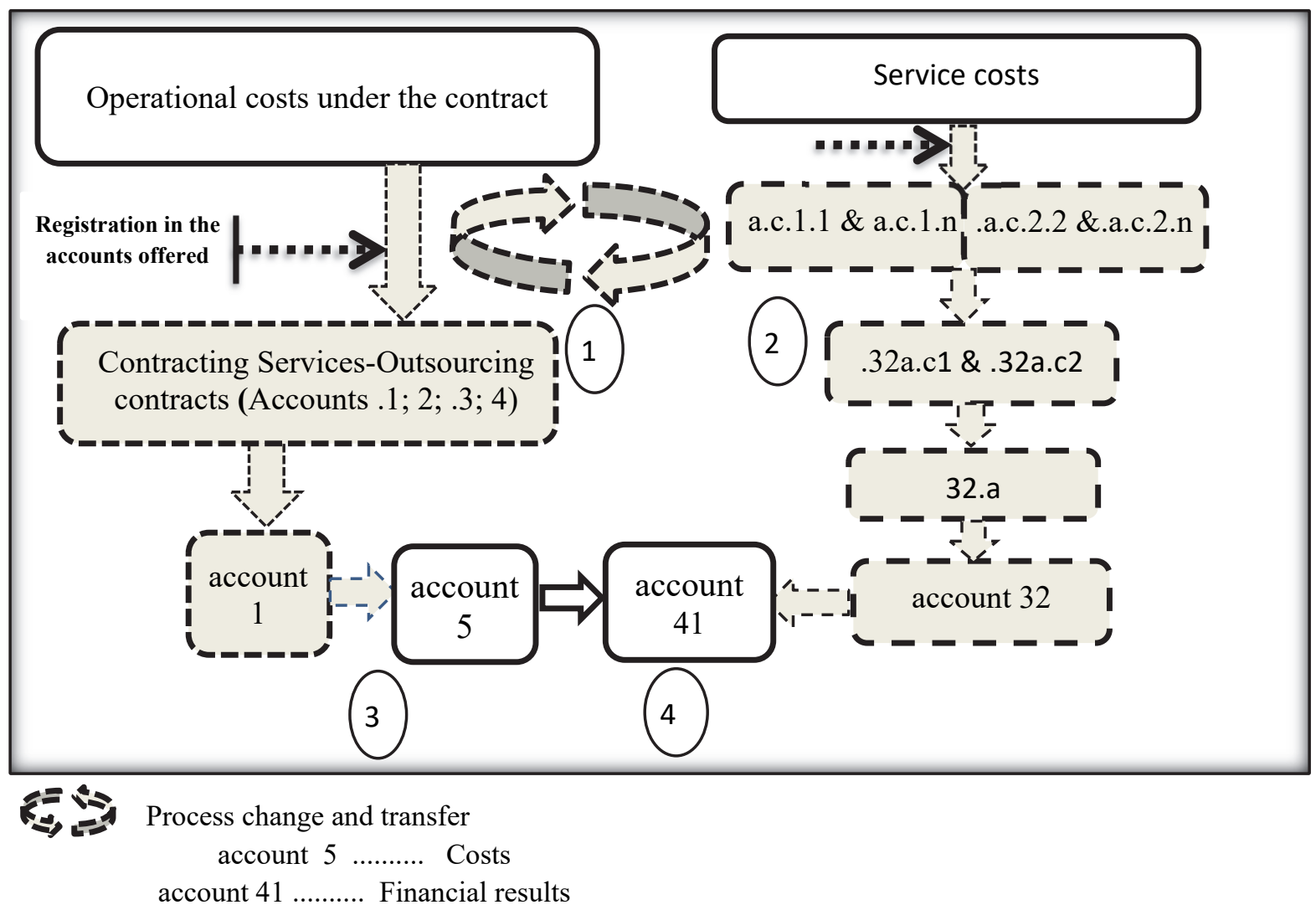

Source: The author's elaboration

Fig. 6. Application model accounting system outsourcing costs

In the given model, the content of management accounting and its organizational form express an inextricable link with the organization, the methodology and technique of maintaining cost accounting methods by financial responsibility centers. Through the use of the methodological unity of accounting and the analytical processes in the development of the cost accounting system in the context of systematizing data within the framework of integrated accounting for all outsourcing agreements, which will serve as confirmation of the fact that accounting outsourcing services are provided. An explanation of the abbreviations is shown in Table 3. The figure shows elements of financial accounting such as costs of outsourcing (outsourcing contract), the trend of using the results of economic activities, the stage of the outsourcing agreement (with the resulting administrative costs) and the cost elements. Account code mapping reflects named items and allows you to collect accounting information through them, forming appropriate levels of detail to calculate your outsourcing costs. Changes in the Chart of Accounts and the disclosure of information about objects in financial statements are determined in the Republic of Iraq by law.

Table 3

Interpretation of operations of the scheme for reflecting the costs of outsourcing in accounting accounts

\begin{tabular}{|c|c|}
\hline № & Explanation of calculations \\
\hline 1 & $\begin{array}{l}\text { From the point of view, transferring the costs to the main outsourcing center and registering the amount of the } \\
\text { contract } 1,2,3,4 \text { to the proposed contracting services (Outsourcing contracts) accounts } 01\end{array}$ \\
\hline 2 & Registration of the cost of servicing the contract - administrative expenses \\
\hline 3 & $\begin{array}{l}\text { Registration, to summarize the analytical accounts of the financial (reporting) period, the costs of outsourcing } \\
\text { services are distributed, which is reflected in the account } 5 \text { (Costs) }\end{array}$ \\
\hline 4 & At the end of the formation of the financial result on account 41 (Financial results) \\
\hline
\end{tabular}

Source: The author's elaboration

In addition, it eliminates the need for multiple data entry for different accounting systems; their conformity, comparability on the basis of a single information space, as well as extensive management accounting are ensured. Due to this multiplicity will improve the quality of accounting information and its use will facilitate the adoption of the right management decisions by all management bodies of the company. The development and approval of these guidelines will ensure the unity of approaches and proper organization of accounting planning calculation and analysis of the cost of outsourcing services. As above, this method 
helped the General Company for the implementation of projects when applying them to work with clarity and correcting these accounts for outsourcing contracts that had problems in the distribution of their costs in the past.

\section{Conclusion}

In order to improve the efficiency of cost management, creating the necessary information base for the implementation of economic analysis and control in terms of the use of outsourcing as a form of organization of accounting, Through additional analytical accounts, which are based on the division of costs by their subject area and functional basis by forming on this account information about calculations, sales, financial results, you can get analytical reports in various slices and time frames. It requires features that focus on finding and realizing the capabilities of the institutions that guarantee their development and stay in an accounting framework that suits their work. The mechanism of classification costs according to the subject and the functional basis is presented by forming information about the accounts of the institutions and the financial results in which its components are reflected, each according to its accounts according to its accounting system used and serves as the basis for determining and recognizing the financial result for each contract, agreement \& object. That allows them to be dynamic and flexible in their internal organization and that allows a high impact, not only in the achievement of objectives companies, but also in the context of the accounting system as a whole. The use of the methodical approach proposed by the authors allows to obtain information in the necessary analytical sections necessary for the implementation of economic analysis and control of this type of enterprise expenses, identifying the causes of deviations. The information obtained allows for a more accurate calculation of the effectiveness of the application of outsourcing services used by the manufacturing establishments in the Republic of Iraq and in other external industrial institutions. The methodological unity that we used in the development of target cost classifications, additions to financial accounts, the disclosure of costs in outsourcing implies compliance with common requirements for information support, planning, accounting, cost analysis. The unity and subordination of the evaluation criteria are the fundamental principle of forming the composition of costs in calculating risks and the effectiveness of outsourcing operations. Thus, the recommended organizational measures for management accounting in financial responsibility centers can significantly increase the efficiency of communication of relevant, reliable, independent, understandable and useful information in the system of economic management methods of financial responsibility centers in industrial institutions. With these conclusions, it is possible to affirm that creating the necessary information base between the companies and the third party requires greater deepening and creativity, to the extent that up to now it has seemed to follow a process parallel to that of productive enterprises in the transfer of some activities, has ended up being expressed in the costs of the structural units of the enterprise which is one of the prerequisites for choosing the form of organization of accounting, which is the most suitable for use in the productive enterprises, to determine the appropriateness and effectiveness of outsourcing.

\section{Disclosures}

Authors declare Special thanks to the General Company for the implementation of projects to help them thanks to the completion of this research.

\section{References}

Алькарави Х. Дж. В. (2018). Современная классификация аутсорсинга на предприятии. Вестник Челябинского государственного университета, 3(60), 111-117. https://cyberleninka.ru/article/n/sovremennaya-klassifikatsiyaautsorsinga-na-predpriyatii

Abdulwahab, R., Alwan, A., Jasim, M., \& Jasim, I., (2019). Technical and Legislative Factors Effects on the Efficiency and Effectiveness of Accounting Information Systems and Supply Chain Management. International Journal of Supply Chain Management, 8(1), 482-487. http://excelingtech.co.uk/.

Ali, D. (2002). The appropriate level of costs. Journal of Economic Sciences, 32, 56-61.

Alkarawy, H. (2013). Advantages and limits of accounting outsourcing in the current economic situation in Iraq // Journal of Investment and Innovation Management, 4, 16 -19. https://www.elibrary.ru/item.asp?id=22002455.

Alsalm, M. (2001). The role of accounting information systems in quality cost measurement and control unpublished doctoral thesis.

Bailal, M. A. (2018). The Importance of Internal Control in Accounting Outsourcing Companies To Increase The Confidence Of Those Requesting Their Services In Iraq. Al-Rafidain Journal, 119(37), 59-80.

De J. P., Dos Reis, C. E., \& Jung, C. F. (2020). Agile Manufacturing Strategy for Outsourced Footwear Production. Innovar, 30(75), 99-118. https://doi.org/10.15446/innovar.v30n75.83260.

Hanan, A. H., (2015). The integration of cost accounting and government accounting and its effect on controlling government spending, Journal Babylon University-pure and applied sciences, 3(23), 1333-1360. https://www.uobabylon.edu.iq.

Hassan, Z. (2000). Mathematical model proposed for the allocation of common sunken costs in industrial facilities energy costs in light of the Agency Theory. Journal of Damascus University, 16(2), 114. 
Heyder, G W. (2018). The mechanism for the transfer of business processes of an industrial enterprise to outsourcing to improve the efficiency of productivity. Journal of Economy and entrepreneurship, 2(12), 885-891. http://journals.intereconom.com/.

Iraqi Financial Control Council, (IFCC), (2011) 'On recommendations and instructions for improving accounting, auditing and financial control based on business entities in Iraq. Government Decree of the Republic of Iraq. No. 31-463. URL: http://www.d-raqaba-m.iq/pages ar/leader ar.aspx.

Jasim, M., \& Mahdi, A., (2019). The Cost of Equity Field in the Market Projection Companies. Opción, 35(20), 1389-1405. https://produccioncientificaluz.org/index.php/opcion/issue/archive.

Kim, N., Alkarawy, H., \& Zdunov, V., (2106), Outsourcing: The Improvement of Accounting System. Journal of Applied Economic Sciences, 4(42), 738-743. http://cesmaa.org/Extras/JAES

Luc, C., \& Luis, C., (2019). The impact of transaction costs in portfolio optimization. Journal of Economics, Finance and Administrative Science, 24(48), 288-311. https://jefas.esan.edu.pe/index.php/jefas/issue/view/108.

Management of financial and accounting, (MFA), (2015). 'Law (95/2004), reprinted in the official gazette, first part. Iraqi legislation. Electronic resource. Legislation: Version Prof Base number 3984. - pp. 106. 2015. Access mode: http://www.iraqld.iq.

Matyushina, Y. (2013). Classification of costs as a prerequisite of enterprise management. Economy and region, 2(39), 98-103. http://eir.nupp.edu.ua/uk/archive.

Matyushina, Y. I., (2015). Impact of techno-economic factors on the cost of commodity output in oil and gas. Economy and region, 1(50), 130-136. http://journals.nupp.edu.ua/eir.

Nasser, A., Karpova, T., Osipov, M, Ostrovskaya, O., (2019). The main directions of reforming the accounting model in Iraq. Catalog Center.

Nassif, J., \& Hassanein, H., (2016). Developing a cost accounting system in the Iraqi environment by adopting cost accounting standards for selected countries. Journal of AL-Turath University College. 20, $198-221$. https://www.iasj.net/iasj?func=issues\&jId=233\&uiLanguage=ar

Ostrovskaya, O. (2019). Questions of accounting operations of outsourcing of works in construction on the example of Russia and the Republic of Iraq. Journal of Izvestia of the St. Petersburg State University of Economics, 5(119), 101-104. https://unecon.ru/sites/default/files/izvestiya no 5-2019-chast_2.pdf.

Rehab, H., Abdulwahab, R., \& Amel, A., (2019).Using (ABC) Method Based on Cost Accounting System to Support Quality Service and Competitive Advantage. International Journal of Innovation, Creativity and Change, 9(7), $289-305$. www.ijicc.net.

Roller, A., (2013). Management cost accounting for responsibility centers in production organizations. Bulletin Udmurt State University, 4, 109.

Sabah K., (2015). Modernizing the unified accounting system to support the implementation of a unified accounting policy in the Iraqi economy. Journal Al-Anbar, 2 https:/www.akhbaar.org/home/2015/4/190010.html

Skakun, L. S., (2015). Evaluating the efficiency of accounting outsourcing: curriculum organization and analysis. International Group of Scientific Works, 3(15), 267-277. http://pbo.ztu.edu.ua/article/viewFile/66330/61818.

Syutkina, M. (2012). Cost classification as a tool for managing vertically integrated businesses (VIB). Bulletin SUSU - Series "Economics and Management", 30(23), 79-81. https://vestnik.susu.ru/em/issue/archive.

Uliana, Y. A. (2013). Conceptual basis of the efficient business management mechanism formation. Ostroh Academy National University Publishing House, series "Economics", 24, 8-14. https://ecj.oa.edu.ua/. 


\section{Appendix}

\section{Table 1}

The Scheme of the reformation (addition) of accounts for the accounting of production costs by responsibility centers (The Sample - Iraq)

\begin{tabular}{|c|c|c|c|}
\hline Data & First level & Second level & Third level \\
\hline Responsibility Centers & $\mathbf{5}$ & - & - \\
\hline Plant No. (1) or other place of business & - & $\mathbf{1}$ & - \\
\hline Production unit & - & - & $\mathbf{1}$ \\
\hline
\end{tabular}

\section{Table 2}

Scheme for repairing (adding) accounts of production costs accounting under contracts according to the production center for some industrial works (The Sample - Iraq)

Source: The author's elaboration

\begin{tabular}{|l|c|c|c|}
\hline Activities under outsourcing agreements & Account Code 3 & Account Code 2 & Account Code 1 \\
\hline Production centers & & 1 & 5 \\
\hline 1. Iron works under Contract 1 & 511 & & \\
\hline 2. Delivery and dismantling under Contract 2 & 512 & & \\
\hline 3. Reinforcing bars under Contract 3 & 513 & & \\
\hline 4. Templates and installation under Contract 4 & 514 & & \\
\hline Service centers & & & \\
\hline 1. Quality control & 611 & & \\
\hline 2. Engineering processes & 612 & & \\
\hline 3. Warehouses & 613 & & \\
\hline 4. Maintenance & 614 & & \\
\hline
\end{tabular}

